\title{
Elevated Serum Levels of Pancreatic Secretory Proteins in Cigarette Smokers after Secretin Stimulation
}

\author{
Göran Balldin, Anders Borgström, Allan Eddeland, Sven Genell, \\ Lars Hagberg, and KJell Ohlsson, Departments of Surgery and Clinical \\ Chemistry, University of Lund, Malmö General Hospital, Malmö, Sweden
}

\begin{abstract}
A в S T RACT The secretory pancreatic proteins in serum were analyzed in a group of cigarette smokers and a control group of nonsmokers before and after intravenous secretin stimulation. None of these persons had any signs of pancreatic disease. In the control group, serum total amylase activity, pancreatic isoamylase, cationic trypsinogen, and pancreatic secretory trypsin inhibitor concentrations varied within the normal range before and after secretin injection. In contrast, the concentrations of these pancreatic proteins in all the cigarette smokers elevated from normal to abnormally high serum concentrations after secretin stimulation. The results indicate a probable toxic effect of cigarette smoking on the exocrine pancreas.
\end{abstract}

\section{INTRODUCTION}

Inflammatory and neoplastic diseases of the exocrine pancreas are increasing. In the United States (1), pancreatic carcinoma is the fourth leading cause of cancerrelated mortality, and at autopsy $2 \%$ of deaths are related to the pancreas (2). Many environmental and chemical agents have been related to pancreatic diseases $(3,4,5)$. Tobacco smoke contains multiple agents with cytotoxic or carcinogenic effects on the exocrine pancreas $(2,3)$, and studies have shown a close correlation between cigarette smoking and pancreatic cancer $(4,6)$.

Reprint requests should be addressed to Dr. Kjell Ohlsson, Department of Clinical Chemistry, Malmö General Hospital, S-214 01 Malmö, Sweden.

Received for publication 12 March 1980 and in revised form 16 April 1980.
There is a need for rapidly improved diagnostic laboratory methods in treating pancreatic disease. This has led to increased interest in the endogenous turnover of secretory pancreatic proteins. Serum amylase and its isozymic forms are well known $(7,8)$, using radioimmunoassay, other pancreatic proteins have been determined in serum, e.g., cationic trypsinogen (9) and pancreatic secretory trypsin inhibitor (10).

Incidently, a rise above normal of some of the secretory pancreatic proteins was noted in a few members of a "normal" group undergoing secretin stimulation tests. These people were cigarette smokers.

The purpose of our study was to compare the effects of secretin stimulation on the serum level of amylase, cationic trypsinogen, and pancreatic secretory trypsin inhibitor in nonsmokers and long-term cigarette smokers.

\section{METHODS}

24 subjects, randomly selected from among students, hospital professional staff, and patients without signs of abdominal disease, including both sexes, aged 25-70, took part in this study. All had smoked cigarettes for 5-40 yr, and at the time of this study smoked 10-40 cigarettes daily. 12 healthy volunteer students and hospital professional staff, aged 25-70, served as a control group. Eight had never smoked cigarettes and four had stopped smoking at least $3 \mathrm{yr}$ before this study. Both the control and smoking groups had an equal number of social drinkers with an average monthly intake of $<100 \mathrm{~g}$ of alcohol. No subject used had a history of alcohol abuse.

Secretin was a product of AB Kabi Diagnostica, Stockholm, Sweden. 75 clinical units in $10 \mathrm{ml}$ of $0.9 \% \mathrm{NaCl}$ was injected intravenously over $2 \mathrm{~min}$. Sephadex G-100 was obtained from Pharmacia Fine Chemicals Inc., Uppsala, Sweden. Monospecific rabbit antisera against human $\alpha_{1}$-antitrypsin and $\alpha_{2}$-macroglobulin are regularly produced in our own laboratory. 
The secretin stimulation test was performed in the morning before breakfast and after a 12-h overnight fast. Cigarette smoking was denied from the start of the fast until completion of the test. Blood samples were drawn from a peripheral vein and collected in test tubes $10 \mathrm{~min}$ before, and 15 and $30 \mathrm{~min}$ after the injection of secretin. After coagulation and centrifugation, about $4 \mathrm{ml}$ of serum was collected from each tube and immediately frozen. The subjects suffered no ill effects.

Total serum amylase activity was performed with the Phadebas Amylase test (Pharmacia Diagnostica AB, Uppsala, Sweden). Normal equals $1.2-5.0 \mu$ cat/liter. ${ }^{1}$ Serum pancreatic isoamylase activity was determined according to Skude (8). Normal equals $0.75-2.9 \mu$ cat/liter. Immunoreactive cationic trypsinogen in serum was determined by radioimmunoassay according to Borgström (9). Normal equals 15-50 $\mu$ g/liter. Immunoreactive pancreatic secretory trypsin inhibitor was determined by radioimmunoassay according to Eddeland et al. (10). Normal equals 6-18 $\mu \mathrm{g} /$ liter. Gel filtration of serum samples was done on a Sephadex G-100 column $(1.5 \times 35 \mathrm{~cm}, 2.4$ $\mathrm{ml} / \mathrm{h})$. Each sample $(0.5 \mathrm{ml})$ was applied and eluted with $0.01 \mathrm{M}$ tris- $\mathrm{HCl}$ buffer, $\mathrm{pH} 7.4$, containing $\mathrm{NaCl}(0.12 \mathrm{~mol} /$ liter) and EDTA $(0.005 \mathrm{~mol} / \mathrm{liter})$. Fractions of $0.9 \mathrm{ml}$ were collected. $\alpha_{1}$-Antitrypsin and $\alpha_{2}$-macroglobulin concentrations were determined by electroimmunoassay (11).

Statistical methods. Comparisons between serum values before and after secretin stimulation were carried out by $t$ test for paired and unpaired observations $(P<0.01=$ significant; $P<0.001=$ highly significant).

\section{RESULTS}

In the control group the serum values of total amylase activity, pancreatic isoamylase, cationic trypsinogen, and pancreatic secretory trypsin inhibitor were within normal limits before, and 15 and $30 \mathrm{~min}$ after secretin injection (Table I, Fig. 1). All subjects in the smoking group, however, showed a uniform increase above the normal range for all parameters determined following secretin stimulation.

Total amylase activity. Before secretin injection, the mean total serum amylase activity in the smoking group was $4.1 \mu \mathrm{cat} / \mathrm{liter}$ as compared with $3.2 \mu \mathrm{cat} / \mathrm{liter}$

${ }^{1}$ Abbreviation used in this paper: $\mu$ cat, microcatal.

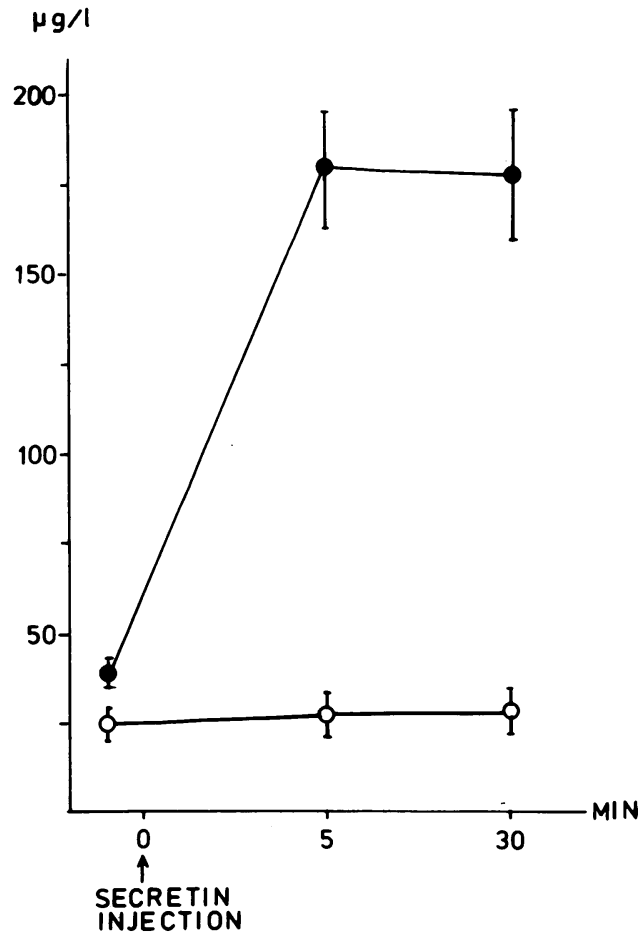

FIGURE 1 Immunoreactive cationic trypsinogen in serum in the control group $(O)$ and the cigarette smoking group $(O)$ before, and 15 and $30 \mathrm{~min}$ after secretin stimulation. Concentration in micrograms per liter. Mean $\pm S E M$.

in the control group. 15 min after the secretin injection, the serum amylase concentration in the smoking group was $7.5 \mu$ cat/liter, and $30 \mathrm{~min}$ after the injection, 8.3 $\mu$ cat/liter.

Pancreatic isoamylase. In the smoking group, the mean serum pancreatic isoamylase concentration was $2.5 \mu \mathrm{cat} / \mathrm{liter}$ before the secretin stimulation. This is significantly above the $1.6 \mu$ cat/liter of the control group. 15 and 30 min after the secretin injection the serum

TABLE I

Total Amylase and Pancreatic Isoamylase Activity in Serum Before and After Secretin Stimulation

\begin{tabular}{|c|c|c|c|c|c|c|}
\hline & & Number & Before & $15 \mathrm{~min}$ & $30 \mathrm{~min}$ & $\begin{array}{l}P \text { before } \\
\text { vs. } 15 \mathrm{~min}\end{array}$ \\
\hline $\begin{array}{l}\text { Serum total } \\
\text { amylase activity }\end{array}$ & $\begin{array}{l}\text { Control group } \\
\text { Smoking group } \\
P \text { control vs. } \\
\text { smoking group }\end{array}$ & $\begin{array}{l}12 \\
24\end{array}$ & $\begin{array}{c}3.2 \pm 0.2 \\
4.1 \pm 0.2 \\
<0.01\end{array}$ & $\begin{array}{l}3.3 \pm 0.2 \\
7.5 \pm 0.7 \\
<0.001\end{array}$ & $\begin{array}{l}3.2 \pm 0.2 \\
8.3 \pm 0.8 \\
<0.001\end{array}$ & $\begin{array}{c}\text { NS } \\
<0.001\end{array}$ \\
\hline $\begin{array}{l}\text { Serum pancreatic } \\
\text { isoamylase }\end{array}$ & $\begin{array}{l}\text { Control group } \\
\text { Smoking group } \\
P \text { control vs. } \\
\text { smoking group }\end{array}$ & $\begin{array}{l}12 \\
24\end{array}$ & $\begin{array}{l}1.6 \pm 0.1 \\
2.5 \pm 0.2\end{array}$ & $\begin{array}{l}1.8 \pm 0.1 \\
6.0 \pm 0.7\end{array}$ & $\begin{array}{l}1.7 \pm 0.1 \\
6.9 \pm 0.8\end{array}$ & $\begin{array}{c}\text { NS } \\
<0.001\end{array}$ \\
\hline
\end{tabular}

Total amylase activity and pancreatic isoamylase activity in serum in control and cigarette smoking group before, and 15 and $30 \mathrm{~min}$ after secretin stimulation. Concentrations in microcatal per liter. Mean $\pm \mathrm{SEM}$. 
concentrations were 6.0 and $6.9 \mu$ cat/liter, respectively, in the smoking group (Table I).

Immunoreactive cationic trypsinogen. The mean concentration of cationic trypsinogen in the test serum was $37 \mu \mathrm{g} /$ liter before the secretin injection with a corresponding value in the control group of $24 \mu \mathrm{g} / \mathrm{liter}$ $(P<0.01) .15$ and $30 \mathrm{~min}$ after the secretin stimulation, the mean values in serum were 176 and 174 $\mu \mathrm{g} /$ liter, respectively $(P<0.001)$ (Fig. 1$)$.

Immunoreactive pancreatic secretory trypsin inhibitor. Before injection, the mean value of pancreatic secretory trypsin inhibitor in the test serum was $13 \mu \mathrm{g} /$ liter with a corresponding control value of 9.5 $\mu \mathrm{g} / \mathrm{l}(P<0.01) .15$ and $30 \mathrm{~min}$ after secretin stimulation, the mean serum values were 22 and $20 \mu \mathrm{g} / \mathrm{liter}$, respectively. $(P<0.001)$ (Fig. 2).

Gel filtration of serum samples obtained from persons in the smoking group before and after the secretin stimulation showed all immunoreactive cationic trypsinogen and pancreatic secretory trypsin inhibitor recovered in volumes corresponding to free cationic trypsinogen $(\sim 25,000 \mathrm{~mol} w \mathrm{wt})$ and free pancreatic secretory trypsin inhibitor $(\sim 7,000 \mathrm{~mol} \mathrm{wt})$. No immunoreactive

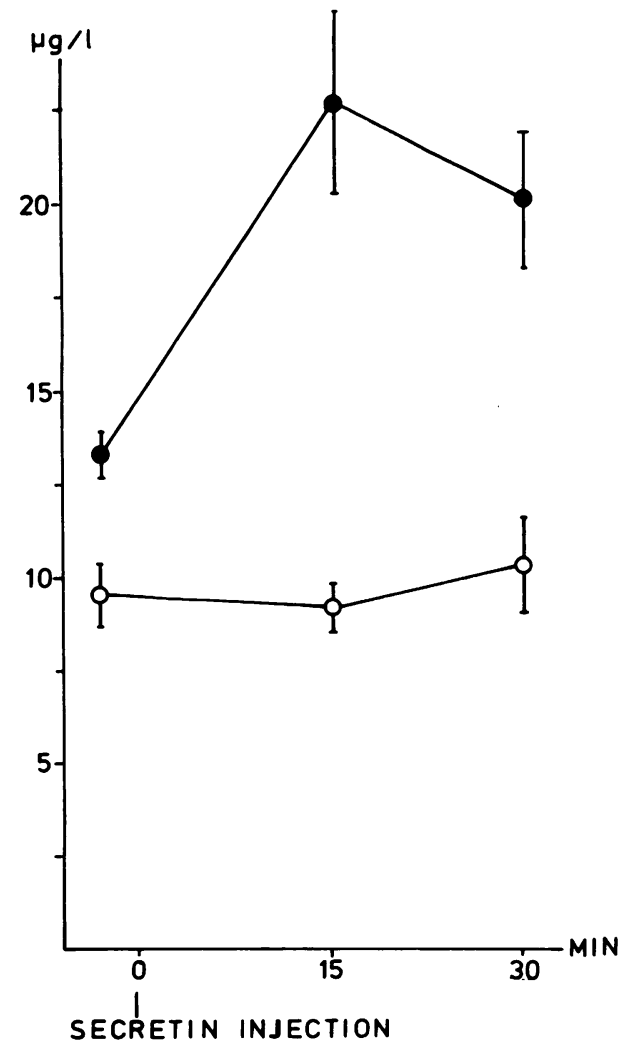

FIGURE 2 Immunoreactive pancreatic secretory trypsin inhibitor in serum in the control group $(O)$ and cigarette smoking group ( $\odot$ ) before and 15 and $30 \mathrm{~min}$ after secretin stimulation. Concentration in micrograms per liter. Mean $\pm S E M$.

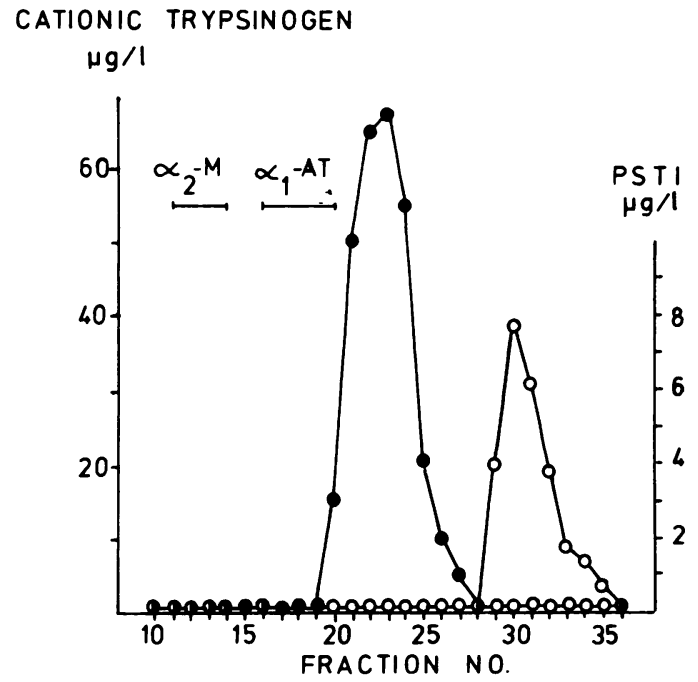

FigURE 3 Gel filtration elution profile of cationic trypsinogen $(O)$ and pancreatic secretory trypsin inhibitor (PSTI) (O) on a Sephadex G-100 column. Serum from a smoker $30 \mathrm{~min}$ after secretin stimulation was applied. Bars indicate elution volumes for $\alpha_{2}$-macroglobulin $\left(\alpha_{2}-\mathrm{M}\right)$ and $\alpha_{1}$-antitrypsin $\left(\alpha_{1}-\mathrm{AT}\right)$. Concentration in micrograms per liter.

cationic trypsinogen was eluted corresponding to $\alpha_{2}$ macroglobulin $(\sim 725,000 \mathrm{~mol} \mathrm{wt})$ or $\alpha_{1}$-antitrypsin ( $\sim 55,000 \mathrm{~mol} \mathrm{wt})$ (Fig. 3).

\section{DISCUSSION}

Serum levels of secretory pancreatic proteins become markedly elevated with obstruction of the pancreatic duct. The increased ductal pressure may lead to movement of zymogens into the periacinar space, where acinar cell damage may be induced upon activation of the zymogens (12). Passage of pancreatic proteins into lymphatic and blood capillaries in the peripancreatic connective tissue can then lead to the elevated serum levels seen in acute pancreatitis (13-16). A tremendous release from pancreas of active trypsin and other pancreatic proteases has been demonstrated during experimental acute pancreatitis (17). Increased plasma levels of pancreatic proteins are occasionally observed in chronic pancreatitis, possibly caused by duct obstruction. Likewise, carcinoma of the pancreas might cause a local obstruction and thereby induce elevated pancreatic enzymes in the circulation (15).

Several groups have studied serum levels of amylase and lipase after secretin stimulation in patients with known disease states (18-21). Some authors have considered this provocative test to be of value in the diagnosis of pancreatic disease (18), although others have found disappointing results (19-22). The results of our investigation using normal subjects have revealed findings not previously well documented. These new 
insights may help explain the false positive results previously reported for individuals with apparently healthy glands. In nonsmoking healthy subjects, conventional intravenous doses of secretin caused no elevation of serum pancreatic secretory proteins. In cigarette smokers, however, secretin stimulation caused three- to fivefold increase of a series of secretory pancreatic proteins in serum within $15 \mathrm{~min}$. None of these individuals had clinical signs or a history of pancreatic disease. Their initial serum concentrations of secretory pancreatic proteins were within the normal reference range, but slightly higher than in the control group. Thus, cigarette smokers seem to have a greater reflux of secretory pancreatic proteins into the blood. This reflux is dramatically increased with secretin stimulation. The exact mechanism behind this increased "leakiness" of the pancreatic gland in cigarette smokers remains to be elucidated. Several alternative explanations are possible, such as "subclinical" pancreatic cell injury caused by cytotoxic substances in the smoke or sustained increased intraductal pressure induced by the complex pharmacological actions of nicotine.

Gel filtration of the serum samples from smokers (Fig. 3) demonstrated that only trypsinogen, not trypsin, is found in the circulation after secretin stimulation. If active trypsin had been present, one would have expected to find it bound to its major serum protease inhibitors, $\alpha_{1}$-antitrypsin and $\alpha_{2}$-macroglobulin (23). This finding also contradicts a possible absorption of pancreatic enzymes from the intestine in smokers (24).

Our study clearly pinpoints an unexpected effect of cigarette smoking on the exocrine pancreas, and further analyses are underway in our laboratory to determine the significance of this finding. The methods used in this study may form the basis for simple tests to unmask functional disorders of the exocrine pancreas caused by exposure to cytotoxic or carcinogenic agents.

\section{ACKNOWLEDGMENTS}

We are indebted to Dr. Staffan Källerö, M.D., Department of Clinical Physiology, Malmö General Hospital, for his valuable assistance.

This work was supported by grants from the Swedish Medical Research Council (project B80-17X-03910-08B), the Swedish Association against Cancer (project 1300-B80-02XA), the Foundation of Malmö General Hospital against Cancer, the Foundation of Thorsten and Elsa Segerfalk, the Foundation of Torsten and Ragnar Söderberg, the Foundation of John and Augusta Persson, the Swedish Tobacco Company, and the Medical Faculty, University of Lund.

\section{REFERENCES}

1. Pledger, R. A., B. R. Bates, and U. Soffiolti. 1975. Introduction: National Cancer Institute Pancreatic Carcinogenesis Program. Cancer Res. 35: 2226-2227.

2. Sarles, H. 1973. An international survey on nutrition and pancreatitis. Digestion. 9: 389-403.
3. Longnecker, D. S. 1977. Environmental factor and diseases of the pancreas. Environ. Health Perspect. 20: 105-112.

4. Wynder, E. L. 1975. An epidemiological evaluation of the causes of cancer of the pancreas. Cancer Res. 35: 2228-2233.

5. Pour, P., F. W. Krüger, S. Althoff, A. Cardesa, and U. Mohr. 1975. A new approach for induction of pancreatic neoplasms. Cancer Res. 35: 2259-2268.

6. Krain, L. S. 1970. The rising incidence of carcinoma of the pancreas-real or apparent? J. Surg. Oncol. 2: 115-124.

7. Wohlgemuth, J. 1910. Beitrag zur funktionellen Diagnostik der Pankreas. Berlin. Klinh. Wochenschr. 47: 92-95.

8. Skude, G. 1975. Sources of serum isoamylase and their normal range of variation with age. Scand. J. Gastroenterol. 10: 557-584.

9. Borgström, A., and K. Ohlsson. 1976. Radioimmunological determination and characterization of cathodal trypsinlike immunoreactivity in normal human plasma. Scand. J. Clin. Lab. Invest. 36: 809-814.

10. Eddeland, A., and K. Ohlsson. 1978. A radioimmunoassay for measurement of human pancreatic secretory trypsin inhibitor in different body fluids. Hoppe-Seyler's Z. Physiol. Chem. 359: 671-675.

11. Laurell, C.-B. 1972. Electroimmunoassay. Scand. J. Clin. Lab. Invest. 124:(Suppl. 29): 21-37.

12. Bockman, D. E., W. R. Schiller, C. Swiyaph, J. H. W. Mutchler, and M. C. Andersson. 1973. Fine structure of early experimental acute pancreatitis in dog. Lab. Invest. 28: 584-592.

13. Borgström, A., and K. Ohlsson. 1978. Immunoreactive trypsin in serum and peritoneal fluid in acute pancreatitis. Hoppe-Seyler's Z. Physiol. Chem. 359: 677-681.

14. Meites, S., and S. Rogols. 1971. Amylase isoenzymes. CRC Crit. Rev. Clin. Lab. Sci. 2: 103-138.

15. Elias, E., M. Redshaw, and T. Wood. 1977. Diagnostic importance of changes in circulating concentrations of immunoreactive trypsin. Lancet. II: 66-68.

16. Brodrick, J. W., M. C. Geokas, C. Largman, M. Fasset, and J. H. Johnson. 1979. Molecular forms of immunoreactive pancreatic cationic trypsin in pancreatic patient sera. Am. J. Physiol. 237: E474-E480.

17. Ohlsson, K., and A. Eddeland. 1975. Release of proteolytic enzymes in bile-induced pancreatitis in dogs. Gastroenterology. 69: 668-675.

18. Burton, P., E. M. Hammond, A. A. Harper, M. T. Howat, J. E. Scott, and H. Varley. 1960. Serum amylase and serum lipase levels in man after administration of secretin and pancreozymin. Gut. 1: 125-139.

19. Dreiling, D. A., and A. Richman. 1954. Evaluations of provocative blood enzyme tests employed in diagnosis of pancreatic disease. Arch. Intern. Med. 94: 197-212.

20. Sun, D. C. H., and H. Shay. 1960. Pancreozymin-secretin test. The combined study of serum enzymes and duodenal contents in the diagnosis of pancreatic disease. Gastroenterology. 38: 570-581.

21. Wormsley, K. G. 1972. Pancreatic function tests. The exocrine pancreas. Clin. Gastroenterol. 1(no. 1): 27-51.

22. Lindstedt, G., P-A. Lundberg, and P. Rolny. 1979. Effect of secretin and cholecystokinin-pancreozymin on plasma CEA concentration in patients with pancreatic carcinoma and pancreatitis. Cancer (Phila.). 43: 2465-2470.

23. Ohlsson, K. 1971. Elimination of ${ }^{125}$ I trypsin-alpha-macroglobulin complexes from blood by reticuloendothelial cells in dog. Acta Physiol. Scand. 81: 269-272.

24. Liebow, C., and S. Rothman. 1975. Enteropancreatic circulation of digestive enzymes. Science (Wash. D. C.). 189: 472-474. 